\title{
Transformation of Traditional Indang Dance to Entertainment Dance
}

\author{
Desfiarni $^{1{ }^{*}}$ Fuji Astuti ${ }^{1}$ \\ ${ }^{1}$ Jurusan Sendratasik, Fakultas Bahasa dan Seni, Universitas Negeri Padang, Sumatera Barat, Indonesia \\ *Corresponding author. Email: desfiarnibm@gmail.com
}

\begin{abstract}
The transformation of Indang dance aims to create Indang dance creations in the form of entertainment as a market leader in the entertainment arts industry and a source of economy for the people of South Solok Regency. Related to this, it is necessary to create a new form of work for entertainment purposes, with the aim of being able to sell and seize the market for the entertainment performing arts industry, which has aesthetic and economic value in Solok Selatan and West Sumatra in general. This research method designed in the form of a qualitative research. Furthermore, this study is aimed to analyze the form of Indang Tagak Dance for entertainment. It is conducted through FGD (Focus Group Discussion) and many experts perspective. In another aspect, this research also uses a multi-disciplinary approach to dance composition, music and choreography (dance creation) as well as a performance artistic approach. The results of the study consisted of three parts; first, describing the Indang Tagak traditional dance which consisted of 16 articles and 65 motifs. Second, designing and imagining the entertainment Indang Dance model by taking 9 articles and 10 motifs from the Indang Tagak traditional dance to be used as a basis for developing movement of Indang dance. In the development of the Indang dance performance model, the entertainment shows 3 dance structures consisting of 3 dance parts, 14 types of movements and 44 motives. After the formation of the indang entertainment dance model, it was disseminated in the community as it was performed at weddings and school events.
\end{abstract}

Keywords: Form Performance, Innovative Indang Dance, and The traditional dance of Indang Tagak

\section{INTRODUCTION}

Indang traditional dance for the people of Koto Parik Gadang sub-district in Ateh South Solok Regency is a cultural heritage, as well as an identity for the supporting community. This traditional Indang dance is a form of performance consisting of oral literature conveyed through Islamic breaths, supported by Rapa'i games. The poetry that sung in the Indang dance is more in the form of majesty or praise to Allah, the prophet's prayers, and the saga about the Prophet.

The performance of the traditional Indang dance is performed by sitting and standing bersyaf by singing the verses while moving the body from left to right, back and forth while hitting the indang (rapa'i) and playing the shawl. Traditionally Indang is used as it means of preaching to spread the religion of Islam which is conveyed from Surau to Surau, at religious events such as: Idil Fitri, Idil Adha, Maulid Nabi, Isra 'Mi'raj, Nuzul Qu'ran and the Islamic New Year.

The growth of the entertainment industry in West Sumatra has prompted the formation of various event organizers and art studios that have emerged in various cities and districts in West Sumatra, so that traditional indang dances are marginalized and there is unfavorable competition. In a way to seize the industrial market requires competition based on quality, the packaging of the performing arts, and the form of the work that is created. As stated by Lindsay, he emphasizes that tourism performance art prioritizes form rather than content, which is said to be "kitsch" art [1]. Furthermore, Umar Kayam (in Lindsay) adds that the art ": kitsch" must also change, in line with movement of time, so it is attractive and can make money [2]. Meanwhile, Sodarsono, stated that entertainment art to attract tourists must be packaged briefly and densely [3]. In line with the expression of Arif E Supriono, in order to create a harmonious relationship between artists and tourism entrepreneurs, works of art for tourism needs must be packed variably in a short duration of time. [4].

For this reason, from the aspect of competition, something that must be achieved is marketing competition, which is competitive so that the entertainment indang dance could seize the indurty market for entertainment performing arts. Based on the explanation above, it is necessary to carry out a transformation of traditional indang dance by packaging the form of creative indang dance with the concept of entertainment, so that it could be enjoyed by the wider community and has a selling value, so that it can improve the economy of the local community. The thing that needs to be done is to construct the indang dance into a new form of nuance, namely the creative indang dance in the context of entertainment, without having to collide with the 
fundamental values in the essence of the traditional indang dance. The same thing was expressed by Koecaraningrat, he stated that the cultural value system is important in realizing the performing arts in order to give a color to the performing arts that were created [5]. In line with the expression (Joko sumarjo, , he states that in choreography it is also necessary to consider aesthetic issues as the natural beauty of works of art that leads to the quality of the creation of the work [6]. Furthermore, Indra Bulan states that in the process of transforming dance apart from movements and costumes, it can also be analyzed both in terms of text and context, so that it becomes something new [7].

Thus, entertainment indang dance can contribute to the development of traditional dance into innovative dance. Traditional Indang Dance can be developed to make new works of more market value, so that they can become an economic source in the lives of the people of Koto Parik Gadang sub-district in Ateh, South Solok district. The transformation of the indang dance is by making changes to the supporting elements of the dance, such as changes in terms of motion, floor patterns, costumes, dancers and the structure of the presentation. Thus, the creation of the Indang entertainment dance could exist, and be able to compete to win the market for the entertainment performing arts industry.

\section{METHOD}

This research was designed in the form of a qualitative research type, which aims to describe the change in traditional indang dance into creative / entertainment indang dance. Data were collected by observation and participants, as well as describing the traditional indang dance form. Furthermore, traditional indang dance used as a source to be developed by creating creative / entertaining indang dance forms. The development is done by designing movements, costumes, floor patterns and dancers in accordance with the needs of the entertainment arts. To analyze the validity of the data, 5 dancers experts / experts from the Dance Education Study Program of the Department of Sendratasik Education, Faculty of Language and Arts and Focus Group Discusition (FGD) were validated on dance movements that had been designed and developed in a new form of choreography with entertainment theme. The input given by the experts, used as material for evaluating the movements designed in the development of creative / entertainment indang dance movements. Furthermore, the movement design was tested on a group of dance study program students in order to finalize the motion design which was used as a creative / entertainment indang dance movement.

\section{RESULT \& DISCUSSION}

Dance is a part of culture that reflects the behavior of society. Soedarsono states that dance was an expression of the human soul that expressed through rhythmic and beautiful movements [8]. Rohkyatmo, he states that dance is a well-trained movement that has been carefully composed to express behavior and taste [9]. The dance could be understood as a movement of the whole body accompanied by sounds arranged according to the rhythm of the song, adjusting facial expressions (and movements) with the content and intent of the dance.

Related to the explanation above, the traditional Indang dance originating from the Koto Parik sub-district in Ateh can be said to be a dance, because this dance moves the body to the right and left while hitting the rapa'i and chanting Islamic words. It can be said that dance is a communication tool that contains certain values that are conveyed through the media of motion.

Indang dance,as the concept of entertainment is a performance of works of art that is alive and moving. In this presentation, entertainment indang dance maintains communication and interaction between the performers and the audience, because the content, the message of the show could be enjoyed by the audience. The same thing was expressed by Indrayuda, that in essence performing arts tend to be played collectively, so that they have the power to be able to interact and be understood and enjoyed by the audience [10]. On the other hand, K. Langer in Soedarsono, he stated that dance as a spectacle is a physical manifestation of human being to be seen by others [11]. In other words, in the process of transforming new dance work, besides having a selling value, it can also be seen and enjoyed by others as a response from the audience.

Performing arts could be realized in the form of a combination of several elements of art such as motion art, acting, sound art which is visualized by the actors as a whole, so that the messages conveyed can be responded to by the audience communicatively. On the other hand, Astuti stated that changes in a performing art can be seen both in terms of form, value, use and function. This statement was found by Astuti in the case of the Bedhaya Sumreg dance in Yogyakarta, namely the Bedhaya Sumreg dance has been transformed from issues of myth and belief in the greatness of kings, to aesthetic issues. Therefore, the issue of traditional performing arts is laden with beliefs, myths and bigotry of its owners. However, traditional arts also cannot be said to be permanent, but will gradually evolve and transform into performances.

As it is known that, in the koto system, the people of Koto Parik Gadang Di Ateh Subdistrict are bound by social norms to regulate human relations in a society in order to create social relationships as expected. The expected relationship between humans is that people have a harmonious life, mutual help, mutual respect, mutual cooperation, and have a high social sense. The Nagari Pakan Rabaa Tengah community which is located in Koto Parik Gadang sub-district where the traditional indang dance has developed, is still living peacefully, patiently, reflecting unity and togetherness in social life. This is a fundamental principle for the Minangkabau community, which is commonly called, "duduak surang basampiksampik, duduak basamo Balapang-lapang", (sitting alone 
narrowing our selves, sitting together feeling comfortable). This shows that the relationship among community members is getting closer. The concept of "mutual cooperation value" is the basis of all activities that are manifested in the attitude of helping help among the citizens of the country which is tied into a system of mutual values as a reflection of human relations with others [12]. Because the people of Pakan Rabaa Tengah are the majority living by farming, the concept of mutual cooperation is what is always practiced in life for the people of Nagari Pakan Rabaa Tengah, so that the relationship between people is getting stronger or longer lasting. For example, in farming activities, the mutual cooperation activity is clear, because the way of cultivating the fields is done by mutual cooperation or it is called pugagi (a form of activity that is carried out in turns or a kind of arisan). This pugagi has several members with various activities, such as wedding party activities also using the concept of mutual cooperation. The habit of mutual assistance and help is still attached to the Nagari Pakan Rabaa community until now.

\subsection{The Art in the middle of Society}

Art in the life of the Minangkabau community, it is a part of customs as jewelry or games for the children of the village. In this village children's game, collective values embraced by the community are manifested. These values and ideologies are applied in the form of sounds (music), traditional movements or dances, chanting and carvings. The results of the embodiment of ideology become traditional arts for the community, and also become ethnic or local cultural identities. In Nagari Pakan Rabaa Tengah, you can still find several types of traditional arts, which are inherited from their ancestors from generation to generation. Based on field observations, there are several traditional arts belonging to the local community that can still be found, namely, Indang Tagak dance, Randai, and talempong music. However, the existence of some of these types of arts cannot be marketed to the global world, because they lack an atmosphere of entertainment.

Some of these types of arts, they are still tied to the time or duration of appearance, the movements and costumes are relatively simple and seem monotonous. Likewise, traditional indang dance with its rich motives for movement must be performed with a very long duration, so that it is not suitable to be presented in entertainment programs that require a short and dense form of presentation, but can be enjoyed as entertainment. Kaeppler in Dibia states that the form of presenting tourism performance art prioritizes entertainment values and visual appeal (visual performance) rather than content that requires serious appreciation and reflection [13]. Based on this, the researcher seeks to develop the traditional Indang Tagak dance into an Indang dance model in the context of entertainment.

\subsection{Visualization of Traditional of Indang Dance}

Basically, traditional Indang dance, the presentation requires a relatively long duration of time, which is approximately 4 hours, so it is difficult to be appreciated by the general public, only certain people can enjoy it. This traditional Indang Tagak dance consists of 16 articles and 65 motifs, so that there are frequent repetitions of the motives in the movements of the traditional indang dance. As a result, it seems that the dance is very monotonous.

On the other hand, the Indang Tagak traditional dance is only danced by male dancers, with a very simple floor pattern, it can be assumed that the main purpose of this indang tagak dance is to convey da'wah, so that when viewed from a choreography point of view it does not prioritize value too much. -the value of beauty and selling value, but at that time the Indang Tagak traditional dance was able to run and live in the community. However, with the development of the arts in the Minangkabau community in general and Koto Parik Gadang sub-district in Ateh, South Solok district, the traditional tagak indang dance in quantity and quality is unable to compete with other "dance" art forms. For this reason, so that indang dance can be appreciated by the general public, there is a need for change by transforming the traditional tagak dance into entertainment indang dance.

\subsection{The Transformations of Traditional Indang Dance to Entertaintment Performance.}

The term "transformation" is closely related to "change" [14]. In this case, it is a change to the elements that support the traditional indang dance into entertainment indang dance. This change was made with the consideration that the traditional indang dance could not compete with other entertainment arts, so that the indang dance had an impact on the extinction of the dance. It needs to be realized that if this traditional indang dance is packaged in the form of new creations with the theme of entertainment it will have a selling value and have a positive impact on the economic development of the community, especially for the dance management practitioners.

In the process of transforming the traditional indang dance to the entertaintment, creations / entertainment have changed the form. The form is a form of dance, as expressed by Hadi, that the form consists of dance elements, namely motion, space and time. These elements are combined in a complete unity to achieve aesthetic vitality [15]. It is in line with the expression Soedarsono, that choreography is a series of elements of dance composition into a complete unity with all aspects such as: motion, floor patterns, music, clothing and dancers (16). On the other hand, Louis Elfet explained that choreography is an act or the choice of movement to become a dance.

Choreography is a job organizing an activity or action, where the action is rooted in human body movements with behavior planning and form planning. In turn, the arrangement of these actions and behaviors is arranged with compositional elements into a dance form [17]. Furthermore, the dance sequence as a result of choreographic work can be seen in the form of a dance structure presentation. Keraf explains the structure is the whole of the relationship between the unity and its parts, which are interconnected between the parts to one 
another[18]. In other words, the structure can be said as a set of relationships between ordered parts, which form a greater unity. Thus, it can be concluded that in the process of transforming the indang dance into an entertainment dance, it cannot be denied that there has been a change as stated by (Rian Hidayatullah, that if the artwork is displayed repeatedly in different times, it will definitely experience changes in terms of This is a change in the traditional Indang dance into entertainment [19].

\subsection{The Development of Indang Dance Movement}

Dance movement is the basic language of movement in communicating ideas or ideas and values contained in a dance to dance observers by Smith [20]. On the other hand, dance is the most important physical experience in human life, therefore it can be said that movement itself is an important symptom that used in traditional dance performances and creative dances such as the Kreasi Indang dance which is derived from the traditional Tagak dance.

Indang dance movement creations / entertainment is a development of the traditional Indang Tagak dance movement which consists of 16 articles with 65 motives of motion, because the traditional Indang Tagak dance movements have a variety of repetitive movements, so that in this dance performance seems monotonous by using a duration of time long (approximately 4 hours), so that only certain people can see it. In turn, these dances cannot be marketed and enjoyed by the general public. In order for the traditional Indang dance not to lose the audience, the monotonous motion and the relatively long duration of the presentation, it is necessary to develop it by creating a creative indang dance model that has an entertainment theme, so that it can be enjoyed by the general public. For this reason, it needs good development in terms of movement. ,costumes, dancers time duration, floor patterns and make-up. Related to this, the traditional Indang Tagak dance is used as a source of development for the creative / entertainment Indang dance movement which in turn creates a form of creative movement that becomes an innovative Indang dance model.

\subsection{Transformation and Development of Indang Entertainment Dance}

The main concept in the development of the creative / entertainment indang dance form is in terms of movement, namely by selecting 9 articles from 16 articles and 10 morifs from 65 traditional Indang Tagak motives that are considered relevant and in accordance with the concept of entertainment. In terms of time duration, traditional Indang Tagak dance has to spend approximately 4 hours, for indang dance the creations / entertainment are packaged in a duration of approximately 7 minutes. Likewise from the dancer's side, if the traditional Indang Tagak dance is presented by male dancers, while in the package of indang dance creations / entertainment is presented by female dancers using costumes and make-up that have entertainment nuances. As for the floor pattern, if the traditional Indang tagak dance tends to use straight lines or in the form of symmetrical and circular lines that seem monotonous, then for the development of Indang dance creations / entertainment will use a floor line pattern that is varied and a symmetrical lines, so it doesn't work. seems monotonous.

\subsection{The Indang Entertainment Dance Movement Development Form}

For the development of dance work, a creative process is needed starting from the initial stimulation process to the composition by Desfiarni, [21]. While Astuti states that in the choreography process, creative potential cannot be ignored, because in the creative process it will manifest something novelty, whether it is not there yet to exist or in the form of a development of the existing one [22]. Meanwhile, Charles and Justin emphasize that choreography is a learning to create dance creatively using dance notation [23].

In the traditional Indang Tagak dance, the structure of the dance is termed an article. In that chapter, there are several motives. Meanwhile, for indang dance, the creation / entertainment part of the dance structure is called a part / variety. For the development of Indang dance, creation / entertainment is carried out by taking 9 articles with 10 motives for traditional Indang dance movements, namely article $1 \mathrm{~b}$ with 2 motives, $2 \mathrm{~b}$ with 1 motif, $6 \mathrm{a}$ with 1 motif, $6 \mathrm{c}$ with 1 motif, $6 \mathrm{~b}$ with 1 motif, $16 \mathrm{~b}$ with 1 motif, $16 \mathrm{c}$ with i motif, 5c, 6b with 1 motif. Furthermore, the 9 articles and 10 motifs are developed into 3 parts, namely, the initial part consists of 3 types with 7 motifs, the core part of the dance consists of 10 types with 26 motifs and the closing part consists of 4 types with 11 motifs, so that the structure of the indang dance is creations. The entertainment arranged in 3 parts with 17 styles and 44 motifs. As for the development process, the movement which is distilled / processed includes aspects of action and effort as well as aspects of space, time and energy. In the process of developing the motive of traditional dance movements, finding forms of action and creative movement efforts in the Indang Kreasi dance. While the development method used is the kinesthetic sequence method, and the results of the development form find the type of pure dance and study, by presenting it in a symbolic way.

\subsection{Floor Design Development / Floor Patterns}

The floor design or floor pattern is one of the most important dance supporting elements in a dance unit, both traditional and creative dance. Floor patterns form a unity in dance, also have an emotional touch that embodies the idea of the dance itself. The floor pattern consists of two basic line patterns, namely straight lines and curved lines. From these two lines can be made with various forms of floor patterns such as triangles, rectangular lines, zigzah lines, circle lines and curved lines. From the forms of these lines that are in dance performances. As expressed by Soedarsono explains that floor design is a pattern that is traversed or traversed by the movements of the arrangement on the floor of the dance room [24]. Based on the opinion of the experts above, that the floor design is the lines traversed by the dancer and forms the dancers in 
making movements on the stage or stage space, and clarifies the lines of motion on the formation carried out by the dancer.

Indang Tagak traditional dance is one form of traditional dance where the floor pattern has one floor pattern, namely two horizontal lines, with the form of one floor pattern in the Indang Tagak Traditional dance, so the impression of the floor pattern is monotonous. For this reason, floor patterns in Indang dance creations/entertainment are arranged in various forms based on the main line elements of the floor pattern, namely straight lines and curved lines. However, the characteristic or identity of the floor pattern from the traditional Indang Tagak dance still appears in the Indang entertainment floor pattern.

\subsection{The Dancers}

Dancers are the most important element in dance presentation. It is said that because the dancer is a person who acts as a channel for ideas or messages to the audience which are expressed through the media of dance movements which are manifested in a series of dances. Related to dancers, Indang dance creations / entertainment are performed by 8 teenage female dancers. Although it is realized that the traditional Indang Tagak dancers are played by men, in the development of the indang dance form, creations / entertainment have been completely overhauled, namely by only featuring female dancers.

There is a fundamental change in dancers, with the consideration that we have to accept the fact that recently women in Minangkabau have got a wider space to involve themselves in the world of art, both as art practitioners, choreographers, and dancers. The existence of women in the world of "dance" deserves attention and appreciation. This, has been expressed by Astuti, she stated that Minangkabau women have redefined their existence in the past [25]. There is a sharp dichotomy between men and women in "dance" artistic activities, but currently Minangkabau women in artistic activities has achieved gender equality, even if it is said to have exceeded gender equality as evidenced by the achievements of Minangkabau women who are active in the world of "dance" and their popularity has spread both at local, national and international levels. This means that the quality of female dancers is not less competitive than that of male dancers. Starting from this, the researcher was inspired to develop this indang dance / entertainment by involving female dancers.

Although the development of creative / entertainment indang dances has involved women, it does not violate the norms that become the reference for ideal Minangkabau women's actions. Both in terms of form of motion, attitudes / behaviors in dance offerings that are shown are still taken into consideration in the form of the development of this creative / entertaining indangan dance. This is in line with Astuti's research results entitled Choreography Learning Based on Local Wisdom, recommending that, although female dancers already exist in the world of dance, they should still distinguish between movements that are appropriate for men and women.
Women may reach their popularity in the world of dance, but all movements remain oriented to their nature as women. Likewise, what is suggested by dance experts/ experts when designing creative/entertainment indang dance movements to see if it is done through FGDs and the suggestions given are no different from what Astuti recommends as well as this also becomes the basis for consideration by researchers when designing dance models. indang this creation/entertainment. Based on the opinions of these experts and not contradicting what has been developed in this creative/entertainment Indang dance, the researcher is very confident that this creative/ entertainment indang dance can be appreciated by the wider community and Minangkabau in particular without causing problems that cause fatality. This is emphasized by Astuti, that even though women have got a great opportunity in dance activities, their movements must be feminine, which is weakly evaluated, which is likened to the philosophy of Siganjua negligence, how come the wickedness is more surreal, but the layout is broken tigo. This means that women must be careful and careful in doing anything, including dance movements [26].

\subsection{Supporting Elements in Dance}

a) The Make-Up and Costumes

Make-up in the art of dance performance is a supporting element which is an integral part of dance performances.The function of make-up in the Indang dance performance is basically to change the face of the dancer according to the character so as to give strength to communication with the audience (Desfiarni),. Related to this 1). Dancers look neat and beautiful as Minangkabau women, 2) help the dancer's expression or embody the graceful and cheerful character of Minangkabau women in dancing Indang entertainment / creations, 3) To emphasize the lines of motion of the graceful and cheerful female characters [27].

Costume or clothing is a supporting element in the art of dance performance. In order to look beautiful and attractive, the costume arrangement must be adjusted to the needs of the dance presentation. Therefore, in the arrangement of costumes and the use of dance clothes, things should be considered, namely; 1) Conformity with the theme of dance / dance characters. In connection with the costumes used in the Indang dance performance, it is showing the character of Minangkabau women who are graceful, polite, and displaying local cultural identity by wearing brackets. 2) Does not interfere with dance movements. In this case, the Indang Entertainment dance movements / creations using brackets do not interfere with the movements performed by the dancer. 3 ) The costumes of brackets used in entertainment Indang dance performances add to the attraction when the dancers perform, look harmonious, and add to the aesthetic values of local Minangkabau culture. On the other hand, Astuti emphasizes that the use of dance for women both in everyday life and in dance performances is related to the values of the duo baleh that must be practiced by ideal Minangkabau women as virtuous women [28]. 


\section{b) Property}

Dance property is a complementary element used by dancers in performing a dance movement. In this case the property used is the indang, a type of instrument used or danced by the dancer when the dancer is dancing the Indang dance. Indang property is danced while hitting Indang which can produce beautiful sounds and can even become internal music in Indang dance. The indang form used in this entertainment/creation Indang dance is approximately $17 \mathrm{~cm}$ in diameter.

\section{CONCLUSION}

Indang dance entertainment with the concept of entertainment can be presented briefly, solidly and can be appreciated by the wider community, because it prioritizes in terms of entertainment, so that it is easy to understand and can be enjoyed. After the transformation of the traditional indang dance into an entertainment indang dance, the dance has a selling value so that it can improve the economy of the local community. Entertainment indang dance can be performed in various events such as entertainment at school, entertainment at weddings and others.

Changes made are by selecting some of the motives of the traditional indang dance movements to be arranged and developed into a form of motion that has a theme of entertainment. Furthermore, from the side of the floor pattern, various floor line designs are used to make it look more attractive. Meanwhile, in terms of dancers, a total change has been made, namely if the traditional indang dance is performed by male dancers, but in the indang dance, the creation/entertainment is carried out by teenage female dancers, so that the dance is presented in an energetic, lively and attractive manner. As for the consideration in choosing female dancers, on the basis of openness to reality which shows that the presence of women in performing arts activities currently gets a wide space and is no less qualified than male dance. Meanwhile, the costumes and make-up conform to the concept of entertainment dance.

The thing that is very concerned about in this development are the nature of dancer. Although there has been a change in the traditional indang dance which is packaged in the form of entertainment indang dance, the basic things of the indang dance principles are not abandoned, for example the indang property is still used. Likewise, even though creative dance/Indang entertainment is presented by female dancers with their expertise, they still maintain the values that Minangkabau women deserve to do, so that the attitudes and behaviors as well as the characteristics of the entertainment indang dance really take into account the nature of a woman who is always guarded and maintained.

\section{REFERENCES}

[1] Astuti F. 2004. Perempuan Dalam Seni Pertunjukan Minangkabau; Suatu Tinjauan Gender. Yogyakarta. Kalika.

[2] ---------- 2003. "Porfil Wanita Dalam Seni

Pertunjukan”. Jurnal Ilmiah Imu-ilmu Humaniora, Volume V Nomor 2: 17-27.

[3] ------------ 2016. "Menumbuhkan Nilai-nilai Kearifan Lokal Melalui karya Tari Koreografer Perempuan Di Sumatera Barat:Suatu Tijnauan Gendet”. Jurnal Ilmiah Imu-ilmu Humaniora, Volume XV Nomor 1: 53-60.

[4] -------- 2011. "Makna Simbolis Sumbang Duo Baleh dalam Seni Pertunjukan Wanita Minangkabau". Jurnal Bahasa dan Seni, Volume X11Nomor 2:139-150.

[5] ---------- 2013. "Menggali dan mengmbangkan Potensi Kreatif Kreativitas Seni PadaAnak Usia dini”. Jurnal Bahasa dan Seni, Volume X1VNomor 1: 48-58.

[6] ----------- 2016. “Esesnsi Nilai-nilai Sumbang Duo Baleh dalam Tari Perempuan Minangkabaui”. Jurnal Garak Jo Garik, Volume X1VNomor 1: 48-58.

[7] ----------- 2019. “The Essence of Siganjua Lalai Values in Dance Movements

of Minangkabau Women”. Jurnal Harmonia, Volume IXX Nomor 1: 37-47.

[8] Afif E.Suprihono 1992. "Tari Untuk Pariwisata Koreografi Padat, Atraktive dan Berwawasan Lingkungan ". Jurnal Pengetahuan dan penciptaan dan Seni, Volume XII Nomor 2: 82-102

[9] Desfiarni 2006. "Pemakaian Tata Rias Wajah Panggung dalam Mata Kuliah Tata Rias dan Busan”. Jurnal Bahasa dan Seni, Volume VII Nomor 1: 22-30.

[10]------------ 2009. "Rangsangan Awal sebagai Motivasi dalam Pembelajaran Koreografi di Jurusan Pendidikan Sendratasi ". Jurnal Bahasa dan Seni, Volume X Nomor 2: 75-80.

[11] Dibia, I, Wayan. 1997. Seni Pertunjukan Turistik dan Pergeseran nilai-nilai Budaya Bali, dalam: Mudra Jurnal Seni dan Budaya, N0.5

[12] Carles, U \& Justin,A,T. 2014.. "TowardsThe Theories and Practce of the dance Arts.”. Jurnal International of Humanitis and Social Science 3 (4):193-206. 
[13] Hadi, Y. Sumandiyo. 2007. Kajian Tari Teks dan Konteks. Yogyakarta: Pustaka Book Publisher

[14] Indrayuda, 2013. Tari Sebagai Budaya dan Pengetahuan. Padang: UNP Press.

[15] Indra Bulan 2016. "transformasi Kuttau lampung Dari Bela diri Menjadi Seni Pertunjukan Tari Pedang”. Jurnal Kajian Seni, Volume III Nomor 1: 58-68.

[16] Kaeppler, Adrienne. 1997. Postmodernism Or The Cultural Logic Of Late Capitalism. London: Verso

[17] Joko Pamungkas 2006. "Estetika Koreografi Sebagi Penunjang Kreativitas Seni Anak Usia Dini”. Jurnal Pendidikan Anak Usia Dini Bahasa dan Seni, Volume IV Nomor 1: 596-600.

[18] Koetjaraninggrat, 1974. Kebudayaan, Metalitet dan Pembangunan. Jakarta: Gramedia

[19] Keraf, Gorys. 1995. Eksposisi. Jakarta: PT Grasindo

[20] Lindsay, Jennifer. 1991. Klasik, Kitcsch, Kontemporer. Sebuah Studi Tentang Seni Pertunjukan Jawa (Terjemahan). Yogyakarta: Gadjah Mada University Press

[21] Murgianto, S. 1983. Koreografi, Pengetahuan Dasar Komposisi Tari. Depertemen Pendidikan Dan Kebudayaan.

[22] Nurgiantoro, Burhan. 1988. Penilaian Dalam Pengajaran Bahasa dan Sastra. Yogyakarta: BPFE.

[23] Rian Hidayatllah 2017. "Transformasi Tari Bedana Tradisi Menjadi Tari Kreasi”. Jurnal Bahasa dan Sastra, Volume XVIII Nomor 2: 178-191

[24] Smith, Jacqualine. 1985. Komposisi Tari Sebuah Pertunjukan Praktis Bagi Guru.Terjemahan Ben Soeharto. Yogyakarta: ASTI

[25] Soedarsono, 1977. Tari-Tarian Indonesia I. Jakarta: Proyek Pengembangan Media Kebudayaan Depertemen Pendidikan dan Kebudayaan.

[26] ,1978. Pengantar Pengetahuan Dan

Komposisi Tari.Yogyakarta: Akademi Seni tari Indonesia.

[27] 1986. Elemn-elemen Dasar Komposisi

Tari. Yogyakarta: Lagaligo.

[28] 1999. Seni Pertunjukan Indonesia \&

Pariwisata. Yogyakarta: SPSI 